\title{
Community development in Chota Nagpur
}

Keywords: community, chotanagpur, christian missions, roman catholic church, anglican church

\section{Introduction}

Community Development is a process by which groups of people try to bring changes for the development of their own community. It is a collective endeavor, but the experiences which are gathered quite beneficial for each individual and communities to grow and change according to their own needs and priorities. This process is accomplished by empowering group of individuals and is needed for the better quality of life of the people in the concerned community. The book under review is named Community Development in Chotanagpur written by Dr. Jyoti Sen. Author of this book was assigned a task by the Anthropological Survey of India for the comparative study of community development among the converted tribal Christians of Chotanagpur in Bihar. This book is the outcome of that extensive study at Chotanagpur in a very lucid manner. In this book he has described the structural organization of three Christian Missions of Chotanagpur at work. He has compared the organizational structural among those three studied Missions. Apart from this he has minutely studied the activities of the Government Community Development Blocks of two districts. He has not even extensively studied the governmental and non-governmental machineries at Chotanagpur district, but he has tried to explore the nuances between these two types of community developmental machineries. In India, Christianity is the third highest religious way of life or religion after Hinduism and Islam. It is known that Christianity was brought to India by the hand of Apostle St. Judas Thomas during 52 AD. History says that Christianity rapidly spread among all other religions in India, especially among the tribals of India. Initially, British Government was not interested to spread Christianity at Chotanagpur district of India; they were more interested to collect forest resource from this region.

The finding of Dr. Jyoti Sen has shown that Christian Missions were consecutively come under the leadership of British emperors. In Chotanagpur district three Christian Missions were at work, viz. the Lutheran Church, the Anglican Church and the Roman Church. This book comprises of seven chapters, viz. Missions and their work, Economic assistance, Schools and hostels, Health and sanitation, Comparison between the three Missions, Community development in two blocks in Hazaribagh district, a comparison between the Churches and community development. The entire work in this book is mainly to compare the work of Christian Missions and Government Organization in the line of Community Development sector. Thus, I think the title of this book was quite appropriate in this regards. At the outset of this book Dr. Sen has briefly spoken about the history of Christian Missionaries at Chotanagpur. He has clearly described how three Christian Missionaries came into existence in the history of Chotanagpur. Those three Christian Missionaries were the Roman Catholic Church of Europe possesses the highest disciples in Chotanagpur followed by the Lutheran Church of Germany and the Anglican Church of United Kingdom. Author has also clearly and minutely described the selection and training process of Jesuit Fathers, Catechists and Nuns of the Roman Catholic Church; German Pastors, Indian Pastors and Catechists of the Lutheran Church; European Missionaries, Indian Clergy and Indian Catechists of the Anglican
Volume 2 Issue I - 2017

\author{
Subhamay Kisku \\ Assistant Professor, University of Calcutta, India
}

Correspondence: Subhamay Kisku, Assistant Professor, University of Calcutta, India, Email uksikyamahbus@gmail.com

Received: November 02, 2017 | Published: November 06, 2017

Church. He has classified his work regarding the approaches of Missions in Chota Nagpur in three ways, these are sources of financial assistance for the Missions, educational approach and regarding health and hygiene related approaches among the common villagers. Author has elaborately collected information about the channels of financial assistance in case of two Christian Missions, the German Lutheran Mission and the Roman Catholic Church. Another important finding of his work is Christian Missions were well aware of future transformation of Chota Nagpur due to huge industrialization. Author has collected large section of his information through extensive fieldwork that has reflected in the section where he has presented the Archbishop's Pastoral letter and he collected that letter when he was present in the morning service of the Catholic Church in Hazaribagh.

Author has also presented large numbers of quantitative data regarding the schools and hostels run by those three Christian Missionaries in Ranchi, Hazaribagh and Singhbhum districts. Not only this, he has also identified the characteristic features of those institutions. Again author has presented his way of collecting data through participant observation by accompanied the nuns to Pondicherry where they went for administer medical aids. He has shown some quantitative and qualitative data regarding health and sanitation of the three Christian Missionaries. He has also described way of work of the Missionaries in the villages. He has exemplified few case studies in this regards to show how much Missionaries were dedicated to their jobs regarding the health of common villagers. The praising part of this book is he has compared three Christian Missions as a whole from his critical views. Here in this section he has shown distinctive features of three Missions in terms of their structure, internal management and approach. He has also put forwarded few general observations where he has shown that how Missionaries were later more interested on developing local leadership instead converting people. He has also viewed that the Missions ultimately recognized the importance of technological advancements rather than merely educational knowledge. They felt the urge of combining three Missions together and develop new leadership among converted and unconverted tribals.

In the second part of his work he has described Community Development in two blocks of Hazaribagh district. For the purpose of this study he has predefined few objectives. To do so he has used classical anthropological fieldwork method of participant observation by attending meetings, direct observation, interview and biography collection of the district and block level Community Development officials. In connection to that he has collected information regarding 
agriculture, animal husbandry, health and sanitation, industries, social education, welfare of Scheduled Tribes and Scheduled Castes. Not only these, after getting unsatisfactory data regarding Community Development programmes author has taken interview of fifty Government Officers of several cadres for double sure. By this method he has found reasons behind unsatisfactory Community Development programmes. For instance, Village Level Workers were feeling inferior to their superior authorities, their participation was not whole heartedly and their future aspirations were to switch into some other jobs. The author has also found that Supervisors were not working dedicatedly for instance supervisors' friends were mainly their colleagues not the local people. Their children were not used to play with village children. This affirms that how author has collected information implicitly. Lastly the author has successfully able to collect information from Block Development Officers regarding the loopholes of Government machineries like 'red-tapism', official harassment and bribes. Another excellent part of this book is comparison between the Churches and Community Development. He has found few similarities and differences between these two types of organizations. He has found that members of Roman Catholic Mission had lifelong recruitment system whereas in Anglican Church, in Lutheran Church and in Government Department it was for stipulated tenure. In mission, members were recruited from known person who has the intention and deliberation of work but in government sector there was no chance of verifying the preparedness for work of the officials. Author has also found that in all cases transfer or posting in different area or department were apparent, which was ultimately using the knowledge for better use. He has found that there was no scope of personal relation between the villagers and the government officials unlike the Missionaries.

In Christian Missions any responsible does not questioned by his juniors due to its vow but in government sector hardly any scope of compulsory obedience as identified by the author. He has found that Government officials were more interested on spending of money rather than quality of positive achievement, whereas, Anglican staffs losses their job, if found works were not done properly. He has also found that Roman Catholic Mission has greater responsibility of following-up works rather than the Anglican Mission and Government Officials. To supplement this statement he has exemplified two examples. He found that superiors of Roman Catholic Mission have mutual co-operation unlike the superior government officials which he termed as 'organizational problem for development work'. Author has found that Missions have better adaptability for giving holidays according to the demands of local people in the primary schools, but it was not happened in the government schools. Here, it should be kept in mind that this work was done much earlier than the present time. Now many government schools in India give their holidays according to the needs of the villagers. At the end of this book the author has concluded his writing by showing few valid arguments that Christian Missions were much more successful than the Government organizations.

The reason is that India was then backward in education, organization and wealth. This statement is also valid in case of present day scenario in India. Non-governmental organization may be in the form of religious organization are coming up in the development sector in India. One reason is in India government organizations are still running shortage of man power and rural people are still in a backward condition. I think the subject matter of this book is quite valid in present day community development scenario of India. Because the way by which author collected his data to supplement his arguments were very much logical and well organized. So, this book has indicated a good research methodological instance in Community Development. Though, author could have done little more justice to his work by putting some conceptual and theoretical content regarding Community Development. Being a scholar of Anthropology, I was looking for those conceptual parts. In spite of this, his work is a tremendous evidence of in-depth empirical study. Last but not the least, author did not forget about to include glossary section in this book, which is quite beneficial for proper understanding of the colloquial terms. I hope scholars of Social Sciences who are specially dealing with development related works, may be quite benefited from this book, though the work was done much earlier.

\section{Acknowledgements}

None.

\section{Conflict of interest}

Author declares there is no conflict of interest. 